\title{
Determinants of German and Japanese Exports: A Comparative Study
}

\author{
George K. Zestos ${ }^{1+}$, Yixiao Jiang ${ }^{1}$, and Clifton Painter ${ }^{1}$ \\ ${ }^{1}$ Christopher Newport University, USA
}

\begin{abstract}
This study investigates the determinants of German and Japanese exports in a comparative fashion. By estimating an autoregressive distributed lag model for each country, we find that the income elasticity of Japanese exports is three times as large as that of Germany's exports. This relative insensitivity to external demand explains why Germany has maintained its export growth whereas Japanese exports started to stagnate after the global financial crisis. Because Germany adopted the euro in 1999, it was able to maintain large trade surpluses. If Germany had instead kept the Deutsche Mark (DM), the DM would have appreciated owing to the Central Bank of Germany's consistent preference for a tight monetary policy, and Germany's trade surpluses would have dissipated. A sharp increase in Japanese foreign direct investment after 2011 has also played a role in reducing Japanese exports after the global financial crisis.
\end{abstract}

Keywords: Autoregressive distributed lag model, Export-led growth, Cointegration, Economic development JEL Classifications: C22, F14, F15, O57

Received 5 December 2020, Revised 23 May 2021, Accepted 2 June 2021

\section{Introduction}

Germany and Japan have striking similarities, starting with their history of colonialization and their recent economic and political renewals after devastating wars. However, the two countries followed very different paths to regain leadership, status, and economic prosperity in the new era of European integration and globalization. This study investigates the similarities and differences in the determinants of Germany's and Japan's real exports using autoregressive distributed lag (ARDL) models.

\footnotetext{
+Corresponding Author: George K. Zestos

Jean Monnet Chair and Professor of Economics, Department of Economics, Christopher Newport University, 1 Avenue of the Arts, Newport News, VA, 3606, USA. Email: gzestos@cnu.edu

Co-Author: Yixiao Jiang

Assistant Professor of Economics. Christopher Newport University, 1 Avenue of the Arts, Newport News, VA, 3606, USA. Email: yixiao.jiang@cnu.edu

Co-Author: Clifton Painter

Research Assistant Christopher Newport University Summer Scholar for George K. Zestos, 1 Avenue of the Arts, Newport News, VA, 3606, USA. Email: clifton.painter.17@cnu.edu

Acknowledgment: We thank Christopher Newport University for providing a Faculty Development Grant and Dr. David Salomon for awarding CNU Summer Scholar grant. We also thank Dr. Thanasis Stengos, Dr. Roark Mulligan, and Dr. Alexander Zestos for reviewing the manuscript and constructive criticism.
} 
We focus on real exports because both Germany and Japan contribute to global economic integration by consistently exporting a variety of consumption and capital goods to the rest of the world. Since its reunification in 1991, Germany has consistently been the world's second largest exporter and the third most complex economy according to the Economic Complexity Index (ECI) ${ }^{1}$. Japan is the fourth largest export economy in the world and the most complex according to the ECI. However, these two countries' trade balances have followed different patterns. In the period from 1980 to 2018, Germany had a negative trade balance in only three years (1992, 1995, and 1999). The Japanese economy, by contrast, did not experience a recurring positive trade balance until 2006. This study aims to shed light on these differences in Germany's and Japan's trade balances by focusing on exports.

We discuss several plausible explanations for these differences. First, global economic activity slowed down following the global financial crisis, which adversely impacted demand for Japanese and German exports. As such, larger income elasticities led to greater reductions in exports. Second, the differences in exports may have resulted from differences in price competitiveness. According to a 2012 Financial Times article, of the world's four leading exporters (i.e., China, the United States (US), Germany, and Japan), only Germany has not been accused of seeking to lower its exchange rate (e.g., Beattie et al., 2012). Japan, by contrast, has more discretion in manipulating the price of its currency. As such, the differences in exports may be driven by the countries' different exchange rate policies. To distinguish between these competing hypotheses, it is important to estimate an export model and examine the elasticity of exports with respect to both external demand and price competitiveness.

Third, the countries' political ideologies and industrial policies are also drastically different.2) We review these differences from a historical perspective in Sections 2 and 3. Fourth, although the industrial policies of Japan and Germany have many historical differences, they have tended to gradually converge. Both countries are now creating positive environments for all sectors of their economies to grow. Nevertheless, the last difference between the two countries is geo-economic in nature. Japan is a member of several economic partnership agreements (EPAs) in East Asia, a dynamic, high-growth region with several globally leading economies, whereas Germany is a member of the EU, a large, highly integrated, and developed area.

1) The ECI measures an economy's knowledge intensity based on the knowledge intensities of the products that it exports.

2) As Zestos and Cooke (2020) note, Germany embraced the notion of ordoliberalism, implementing fiscal discipline and generating public account balances or surpluses and current account surpluses for many years. Japan, in contrast, has one of the highest ratios of public debt to gross domestic product (GDP) among developed countries. 


\section{Literature Review}

\section{A. Seminal international trade theories}

The two cornerstone international trade theories that explain exports are Smith's (1776) theory of absolute advantage and Ricardo's (1817) theory of comparative advantage. According to these theories, countries export the goods that they can produce more efficiently (i.e., at the least cost) in terms of the units of labor needed to produce a unit of a particular commodity. Thus, both theories employ the labor theory of value. The theory of comparative advantage is still considered the most important theory for explaining international trade. The cost of production, however, is not measured in terms of the labor units needed to produce one unit of output but rather in terms of the opportunity cost of production (Haberler, 1936).

Heckscher and Ohlin, two Swedish economists, developed an international trade theory that moves beyond the contributions of Smith (1776) and Ricardo (1817). Nobel Prize winner Paul Samuelson $(1948,1949)$ also contributed substantially to this seminal theory, known as the "factor proportions theory," which explains why countries develop comparative advantages in certain commodities. According to the factor proportion theory, countries have comparative advantages in the commodities that intensively use their relatively abundant factors of production. The Heckscher-Ohlin (H-O) theory has proven useful for explaining trends in international trade and in understanding why countries develop comparative advantages in some commodities and not others 3 ).

Surprisingly, an early empirical test of this model by Leontief (1953) rejected the H-O hypothesis. Leontief employed the input-output methodology in a study of US data from 1947. Because the US was considered a capital-abundant country, it was expected to be exporting capital-intensive goods and importing labor-intensive goods. The results of this study were very surprising to academia and have since become known as "The Leontief Paradox." This study immediately triggered a number of empirical studies, almost all of which initially reaffirmed the Leontief Paradox. The paradox, however, has long since been resolved, as researchers modified the model to include, for example, additional and nonhomogeneous factors of production.

The H-O model was further modified by various scholars and tested empirically. Vanek (1968) kept the two-country assumption but expanded the model to include many production factors. He considered trading commodities as equivalent to trading factor services; in other words, importing labor-intensive goods is the same as importing labor services, and exporting capital-intensive goods is equivalent to exporting capital services. Both before and after Vanek's (1968) contribution, several researchers tried to expand the original model by including more

3) The model is extensively popular among economists and students and pertains to two countries, two commodities, and two factors of production. Thus, it is popularly known as the $2 \times 2 \times 2$ model. 
than two goods, factors of production, and countries. However, problems arose in deriving the expected theoretical results in the presence of factor price equalization (Baldwin, 1971; Bhagwati, 1964).

Horiba (1974) expanded upon H-O theory using a general equilibrium model with three countries and multiple factors of production assuming factor price equalization. Several authors found that the export sector's performance depends on the characteristics of exports per se. When countries produce high-tech exports, the export sector is highly productive (Feenstra \& Kee, 2008; Hausmann et al., 2007). Lee (2011) made the same argument; economies tend to grow more rapidly when they increasingly specialize in exporting high-tech goods as opposed to traditional or low-tech goods. This argument clearly applies to both Japan and Germany.

However, the lack of disaggregated data on exports has forced the vast majority of researchers to use aggregate export data. Using disaggregated OECD export data for 20 manufacturing industries from a group of 71 countries between 1970 to 2004, Lee (2011) demonstrated that characteristics of the disaggregation play a major role in determining the productivity and success of particular export industries. Indeed, countries specializing in high-tech industries are the most successful exporters. The study utilizes Balassa's (1965) export specialization index, which is widely used to measure the revealed comparative advantages of specialization in international trade for $j$ industries and $i$ countries 4 ).

\section{B. Determinants of exports in Japan and Germany}

According to the theories mentioned above, the two key determinants of exports are economic activities in export markets (i.e., external demand) and price competitiveness (Houthakker \& Magee, 1969). Increased economic activity in destination countries and improvements in price competitiveness should lead to an increase in exports. Empirically, external demand is usually proxied by the importing countries' GDPs, and price competitiveness is proxied by the real exchange rate (ER) or the terms of trade (TOT). Both the ER and the TOT reflect a country's comparative advantage, as discussed previously, but they compare that country's performance in terms of cost and productivity with that of another country.

Although existing studies unequivocally find that external demand has a positive impact on exports, the estimated long-run relationship between price competitiveness and exports is less clear. Most studies, including those of Lapp et al. (1995), Clostermann (1996), and Strauss (2004), find that the absolute value of the relative price elasticity is close to one. In other words, a one percent gain in price competitiveness leads to nearly a one percent increase in exports. However, when the analysis is performed for different importing countries and regions,

4) The empirical work is carried out by estimating baseline regressions in which the dependent variable is country $i$ 's real income per capita. The main independent variable is country $i$ 's Balassa index for industry $j$, denoted by $B_{i j}$. Additionally, each regression includes a vector of control variables. 
the price elasticity can substantially deviate and is even statistically insignificant in some cases. For instance, Hooper et al. (1998) find that the average price elasticity of the Group of Seven countries to non-EU countries is only 0.4 , whereas the price elasticity of exports vis-à-vis France is 2.1. Similarly, Kappler and Radowski (2003) find that the price elasticity of German exports to the United Kingdom (UK) is 1.4 .

Japan trades frequently with countries in East Asia.5) Thorbecke and Kato (2012b) find that exports of capital goods depend not only on exchange rates but also on the national incomes of the importing countries and downstream countries' exports to the rest of the world. Using global GDP (minus Japan's GDP) as a proxy for external demand, Jiang et al. (2020) find that the income elasticity of Japan's exports is 11.81, which is nearly five times the price elasticity.

No consensus has been reached on the impact of the exchange rates on the trade balance in Japan. In addition, few studies use real exports as the dependent variable, as this study does. For instance, Shimizu and Sato (2015) employ an ARDL model and find that ERs had a nonlinear impact on trade balances before 1999, a phenomenon known as the $J$-curve6). Bahmani-Oskooee and Goswami (2003), in contrast, find no evidence of the $J$-curve in the short run or any significant relation between the trade balance and the effective exchange rates in the long run using aggregate data for the period from 1973 to 1998. Studies continue to examine the nonlinear or asymmetric effects of exchange rates on macroeconomic variables. For example, using a nonlinear ARDL model, Bahmani-Oskooee and Mohammadian (2017) find that a strong yen seems to hurt domestic production in Japan in the long run, whereas a weak yen seems to have no effect on the trade balance.

Several empirical studies have attempted to estimate vector error correction models (VECMs) relating exports, external demand, and price competitiveness in Germany. These studies find that the relative importance of different export determinants is changing over time. Based on trade data from 1980 to 2004, Stahn (2006) finds that external demand and price competitiveness are equally important for determining German exports. However, from 1993 to 2004, external demand had a much stronger impact than price competitiveness. Thorbecke and Kato (2012a) find that a ten percent appreciation of the exchange rates reduces German exports by six percent. Most recently, Neuman (2020) finds that the ER significantly affects Germany's exports outside the Economic and Monetary Union (EMU) but not its intra-EMU exports. Evidence also suggests that structural factors related to European integration boosted export growth (Stephan, 2006).

In light of these studies, we make several observations. First, both Germany and Japan export large quantities of capital goods (e.g., machinery, integrated circuits, etc.). The production of

5) As an important trading partner in East Asian value chains, Japan specializes in producing large quantities of sophisticated capital and intermediate goods and exporting them to neighboring countries. In 2017, 57\% of Japan's exports went to its Asian trading partners, such as China (20\%) and South Korea (7.8\%).

6) Bahmani-Oskooee and Ratha (2004) provide a comprehensive review of the literature on the $J$-curve. 
such goods often requires importing the relevant input materials (e.g., valves, insulated wires, etc.). The resulting correlation between exports and imports justifies our inclusion of real imports as an independent variable in our model and empirical framework. Second, many previous studies rely on error correction models and the Johansen procedure to detect long-run relationships among the included variables. These methods require all series to be stationary in first differences. However, some time series are in fact stationary in levels when we include the most recent trade data up to 2018, making the ARDL model the only correct framework.

\section{A Historical Primer on the Birth of the Modern States of Japan and Germany}

Before describing the data and the econometric framework for our study, we provide an overview of the history of Japan and Germany from the mid- $19^{\text {th }}$ century to World War II (WWII). Presently, both countries rely heavily on exports to propel economic growth. Reviewing their historical paths, especially their colonialization policies, can help to better understand how these two countries arrived at economic policies and development plans centered on their exports.

Although Japan's history goes back to the Paleolithic era, the modern state of Japan dates back to 1868 , when power over the country was taken from the Great General (Shôgun), a hereditary military leader, and given to Emperor Meiji, which means "enlightened rule." Thus, 1868 marks the end of seven centuries of feudalism and the gradual beginning of the modern Japanese state. The transformation is related to the intrusion of European countries and the US, which forced the Shôgunate to open up trade with these countries under adverse terms for Japan.

Under the new regime, a sequence of major innovations was launched to transform Japan into a new country, mirroring the development of Japan's contemporary European counterparts. Japan's feudal lords lost their domains, and their armies were dissolved. They were replaced by prefectures and a modern national army similar to those of the US and Europe and based on a conscription system. Similarly, social classes were abolished, creating a more egalitarian society. A new tax system was also adopted to collect cash instead of rice from farmers to finance the government budget. At first, the government undertook many economic activities that eventually privatized but subsidized some of these production efforts, laying the foundation for Japan's contemporary mixed market economy.

The highest priority of the early Meiji government was avoiding colonization by Western powers and remaining independent. This fear, as noted by Ohno (2006), motivated Japan to aggressively adapt to Western systems and absorb technologies while still maintaining national unity and identity. After its successful modernization during the Meiji era, however, Japan became a new threat to East Asia and the world. 
Japan won a war against China's Qing Dynasty in 1894 and 1895 and colonized Taiwan and the Liaodong peninsula of China as a result. Its economic management of Taiwan turned out to be very successful. By issuing bonds denominated in foreign currencies, the government was able to build transportation infrastructure and education systems. The colonialization of the Liaodong peninsula, by contrast, was not as smooth because the northeastern region of China remained under Russian influence. From 1904 to 1905, the Japanese-Russian conflict escalated into a war, which perhaps surprisingly ended in a victory for Japan. That naval victory made Japan a first-class military state that was comparable to Western powers.

To some extent, these colonies facilitated the development of Zaibatsu, that is, conglomerate businesses owned by politically well-connected entrepreneurs (Seisho). With free access to larger foreign markets, these large firms could acquire capital and labor at cheaper prices. For example, Nissan, a well-known multinational firm established in 1928, heavily invested in China's Manchuria region, which was occupied by Japan in 1931. Ohno (2006) notes that the strong expansion of the heavy chemical industry in the 1920s also contributed to the growth of Zaibatsu in a variety of industries, including steel, chemicals, and electrical machinery. Next, we describe Germany's history in a similar way.

The modern German state was founded by the ambitious leader of the East German State of Prussia, Otto Von Bismarck. In 1866, Bismarck found an excuse to declare war on Austria and won easily within seven weeks. To assume the leadership of all German states, however, Bismarck needed another military victory. He focused on neighboring France, which the Germans held in low esteem since the Napoleonic wars. Bismarck launched a war against France in 1870 that lasted for one year. All German states sent soldiers to fight their common enemy. After several battles, Prussia won the war; the last battle was the siege of Paris in January 1871.

In the historic palace of Versailles, Bismarck gathered all of the German representatives, including kings and princes, and proclaimed the establishment of the new empire (state) of Germany. Ironically, the new German state came into existence in the capital of a foreign occupied country7). Germany then established colonies, as was customary among European powers. When the new German empire experienced a severe recession from 1873 to 1879 , exports were the solution to its economic crisis. Since then, colonies were seen not only as a source of resources, such as raw materials, minerals, and agricultural products, but also as outlets for German exports, thus boosting economic growth.

Germany occupied and created colonies in 22 countries, according to officially established modern United Nations definitions, on several continents. Most of its colonies, however, were in Africa, including some large countries, such as Nigeria, Ghana, Uganda, and South-West Africa, now called Namibia. Namibia was 1.5 times as large as Germany, but Germany occupied

7) This situation was more than sufficient to create concerns about this German state's peaceful coexistence in Europe and the world. 
and claimed it as a colony despite the fierce resistance of the Herero, the Nama, and other tribes. In 1904, the Herero tribes revolted against the forced trade and the occupation of their country, killing 61 German settlers8). As a reprisal, General Lothar Von Trotha, the head of the German military forces, ordered the killing of every male member of the Herero tribe and drove all of the children and women through the Omaheke desert.

General Trotha's killings constituted the first genocide of the $20^{\text {th }}$ century, as more than 80,000 people died in battle, from thirst, from starvation, from disease, in concentration camps, or by overwork, as some Herero were given as slaves to German settlers. After that, Germany was at the epicenter of both world wars. These wars created extremely difficult living conditions for millions of innocent people throughout the entire world.

At least 20 million people were killed as a result of World War I, and Germany received all of the blame for the war. Severe punishments by the Allies in the form of war reparations increased public debt, leading to bankruptcy, hyperinflation, and massive unemployment, ending the Weimar Republic in 1932 (Myerson, 2004). In the 1930s, the Nazi party was elected to the government, and they led Germany, along with its Japanese and Italian allies, to the most catastrophic war of all time, WWII. This war left at least 50 million dead, including six million Jews in the Holocaust, and created widespread misery, despair, and chaos.

\section{Modern Japanese and German Industrial Policies}

In addition to the aforementioned historical events, another factor that has shaped the current export sectors of Japan and Germany is their respective modern industrial policies. The end of WWII marked new chapters in both countries' histories. Both countries were influenced by the same Allied occupying forces, which had almost identical objectives. The Allied forces aimed to assist both countries in rebuilding infrastructure and promoting economic development.

We highlight three institutional differences between the modern industrial policies of the two countries, as follows. First, after WWII, the Japanese government identified certain industries and supported the development of their exports via appropriate policies, whereas government intervention was minimal in Germany under a policy based on ordoliberalism. Second, German industry has benefited geopolitically from foreign direct investment (FDI) and exports to the large European Union (EU) market. Japan, by contrast, faced growing competition from neighboring countries in East Asia. Third, unlike Japan, Germany announced in 2016 that it would pursue a green economy by ending the use of nuclear and fossil fuel plants.

8) Later, the Nama people also revolted. 


\section{A. Japan}

A unique aspect of Japanese industrial policy after the end of WWII was the dissolution of Zaibatsu enterprises, the large, vertically integrated conglomerates that owned several firms in diverse economic sectors $\left.{ }^{9}\right)$ These enterprises were dissolved after 1945 and replaced by Keiretsu, that is, clusters of enterprises that are horizontally integrated via cross-shareholdings of stocks and are vertically linked with other businesses practicing diverse economic activities. Keiretsu created strong relations between assemblers, input suppliers, banks, and distributors. As a result, powerful and mutually beneficial linkages that lasted until the 2000s were formed among all firms. Keiretsu, however, was challenged by the financial crisis in the middle of the 1990s, which reduced companies' values when the stock market drastically declined (Mosk, 2000).

After WWII ended, different Japanese governmental agencies (ministries) were responsible for the formation of industrial policies in different periods. These policies influenced specific firms at the micro level as well as entire industries. Immediately after the end of WWII (19451949), the Ministry of Commerce and Industry was in charge of industrial policy. This period was extremely difficult for Japan, as its economy was devastated. Japan lost both its colonies and its ships during the war and could not import food or raw materials. The resulting food shortages led to starvation. Very high inflation was inevitable, and, thus, the Japanese government provided subsidies and monetized its public deficits. Japan was under occupation only by the US10).

The Japanese government targeted and supported certain industries that it considered strategically essential, such as coal and steel. The US soon realized that it would be advantageous to assist Japan in becoming a prosperous country by adopting capitalism and by winning the Cold War against Communism. The US government sent Joseph Dodge to assist Japan in its transition to a market economy. Thus, in 1948, the Dodge Plan, a stabilization plan, was launched to control new loans and the budget and establish a new ER system ${ }^{11)}$. Furthermore, the Ministry of Trade and Industry (MITI) created the necessary financial framework to supply funding for strategically essential industries (Okazaki, 2007).

Between 1949 and 2001, the MITI was the governmental agency responsible for industrial policy and trade. Early in this period, the MITI created the financial framework that channeled funding to targeted firms and industries. First the Reconversion Financial Bank, which raised funds by selling bonds to the Japanese government, was established. Thereafter, the MITI extended loans to strategically chosen firms at low subsidized interest rates. The Japan Development Bank and the Export Bank of Japan were introduced in 1950 and 1951, respectively, and the latter was renamed the Export Import Bank of Japan in 1952. The MITI continued its strategic

9) These conglomerates were owned by very wealthy families.

10) In contrast, Germany was occupied by four countries and was ultimately divided into two countries.

11) The Ministry of Commerce and Industry was able to set different implicit ERs for each commodity, as it was setting them in terms of both dollars and yen. 
targeting, but when certain industries lost their comparative advantages, it bought and shut down firms in those industries.

During the period from 1951 to 1960, the MITI helped certain industries increase their international competitiveness (i.e., catch up). The industries targeted for this purpose included shipbuilding, chemical fertilizers, synthetic fibers, and electronics, among others. The MITI also targeted new industries when it was certain that economic growth could be achieved if firms in those industries increased their production for exports, attaining economies of scale. Electronics and automobiles are two such industries. The MITI undertook several measures in coordination with other ministries to provide strong protections for these industries. Tariffs, import quotas, nontariff trade barriers, subsidies for research and development (R\&D), and subsidized lowinterest-rate loans were all protective measures adopted temporarily until the firms developed comparative advantages and were ready to compete internationally. The automobile industry is an example of a new industry that was subsidized (Nishijima, 2012).

At the end of WWII, automobile production was nearly zero until the MITI began protecting automobiles based on the infant industry argument. Thus, tariffs and subsidies were extended to auto manufacturers and to parts suppliers (subcontractors) based on Keiretsu production link $\mathrm{s}^{12)}$. The industrial policy employed by the MITI during the early years after WWII played a crucial role in the success of the Japanese auto industry. However, after a long period of trade liberalization, all trade barriers were removed by 1978. Other factors contributed to the success of Japan's auto industry besides its industrial policy. These factors include the undervalued ER between 1960 and 1985 and the production organization model (i.e., Keiretsu). Lastly, Japanese production innovations, particularly the use of robots in precise assembly-line production, put the Japanese automobile industry ahead of all foreign competitors, which strived to catch up for many years ${ }^{13}$ ). Notably, although Japanese industrial policy was partially credited for these successes, many other industries thrived during this period despite the fact that they were totally independent and thriving without governmental protection (Nishijima, 2012).

From 1953 to 1970, Japan experienced marked economic growth that many economists attributed to its large export sector. As a result, this period often is referred to as the "miracle growth" period. Large trade surpluses with the US nevertheless created friction, which impacted Japanese industrial policy. Japan responded by accepting voluntary export restraints and increasing its FDI to other Asian countries and to the US, reducing trade frictions. At the same time, Japan's industrial policy faced numerous constraints resulting from Japan's membership in international organizations.

12) Imports on inputs to production entered the country without tariffs.

13) At least in the US, this production method saved car owners from frequent and bothersome automobile breakdowns. It also served as a huge incentive for the American car industry to improve its quality, which almost eliminated the frequent sight of highway shoulders littered with disabled vehicles. 
In 1955, Japan became a member of the General Agreement on Tariffs and Trade (GATT) and consequently had to comply with multilateral trade negotiations agreements that led to trade liberalization programs. For many years, tariff reduction schedules pertained only to manufacturing goods. ${ }^{14)}$ In 1964, Japan joined the International Monetary Fund (IMF), which required the removal of ER controls on current account transactions. In the same year, Japan also joined the Organization of Economic Cooperation and Development (OECD) and began liberalizing its capital flows, starting with FDI, in the 1970s. These two memberships had major impacts on Japan's industrial policy, which was adjusted accordingly (Kawai \& Urata, 2012).

Japan's industrial policies therefore changed drastically, initially guiding industries through the reallocation of resources to catch up by promoting certain sectors that were considered strategically essential. After that, industrial policies aimed to create capital-intensive industries. More recently, industrial policies have aimed to transform the economy to one based on technology and knowledge. Thus, the government is responsible for facilitating and disseminating knowledge to all industries. At the beginning of the third millennium, radical changes were introduced, including new industrial policies. These changes were the result of the 2001 election of Prime Minister Koisumi, who introduced structural reforms in the economy aiming to transform Japan into a market economy with minimal or no government interference. The MITI was abolished and replaced in 2001 by the Ministry of Economy Trade and Industry (METI), which is a completely different organization from its predecessor. The METI's new industrial policies were designed to confront threats to Japanese industry and its displacement in the world market by rising Asian economies, particularly China and Korea (Akkemik, 2015). At the turn of the century, Japan began pursuing trade and investment liberalization via the formation of EPAs. The latter go beyond free trade agreements (FTAs), as they provide for reciprocal integration, among other provisions. Japan found EPAs to be very important for domestic firms, which were discriminated against abroad as a result of existing FTAs. In addition, frictions with the US and slow trade liberalization under the Doha Round of trade negotiations induced Japan to seek other avenues to support its economy. Since 2002, Japan has signed EPAs with seven member countries of the Association of Southeast Asian Nations, Mexico, Chile, and Switzerland. It has signed many bilateral and a few multilateral EPAs, mostly with countries in East Asia. These agreements have boosted regional integration in East Asia by contributing to the economic growth of a region characterized by dynamic economies, such as China, Korea, Vietnam, and many others (Kawai \& Urata, 2012).

14) In 1995, GATT became the World Trade Organization (WTO), which is still responsible for trade liberalization and resolving trade disputes between WTO member countries. 


\section{B. Germany}

Germany moved in the opposite direction by encouraging business clusters and promoting competition among businesses. Germany's first government, formed in 1949 by the Christian Democratic Union (CDU) party, adopted economic and industrial policies dictated by the economic and political ideology of ordoliberalism. This ideology is based on an economic and political school of thought that strongly embraces and promotes a free market economy with only minimal government interference. Ordoliberalism influenced German economic and industrial policies after the end of WWII. A minor exception is a short interval in the 1970s when Germany's Social Democratic party (SPD) was in power. The CDU is one of the two major political parties in Germany15). However, the political and economic system that prevailed in Germany until the early 1990s was a social market economy. This system also supports a market-based economy, but the market is supplemented by a safety net provided by the government for its citizens, which promotes a very liberal social welfare system (Zestos, 2016).

Germany's history from the colonial era to modern times is similar to Japan's in many ways. Both countries evolved into wealthy democracies based on an export-led growth model. However, one major difference sets the two countries apart. Japan is an island, whereas Germany is part of the European continent, which was united in the past only by force (i.e., occupation by another European country). In the middle of the $20^{\text {th }}$ century, however, European countries began launching many voluntary programs to attain economic and political unification in a departure from their history. After many destructive wars, including World Wars I and II, European governments sought a way to avoid any future fighting. This aim was to be achieved through unification to form a continent for which borders serve no purpose. The unification process was intended to be gradual, starting with economic integration.

In 1950, six European countries established the European Coal and Steel Community (ECSC) with the Treaty of Paris ${ }^{16)}$. The ECSC created a common market for coal and steel; these countries placed the production and distribution of the two commodities, which were means of war, under a supranational authority. This arrangement warranted the protection of the European people from aggressive neighboring countries. In 1957, the same six countries signed two more treaties, with the Treaty of Rome establishing the European Economic Community (EEC) and the European Atomic Energy Community, thereby creating a common market for all commodities ${ }^{17)}$. In 1992, the EEC launched the Single European Market to transform the EEC into a true single market that allows the free movement of goods, capital, and people.

15) In this discussion, the term "Germany" refers to West Germany prior to 1990. After the collapse of the Berlin Wall in 1989, "Germany" refers to the unified country, which includes both West and East Germany.

16) These countries are Belgium, France, Germany, Italy, Luxembourg and the Netherlands, which have since been referred to as the original six.

17) Atomic energy being supervised by a supranational authority provides a feeling of safety to Europeans. 
Lastly, with the Maastricht Treaty in 1993, eleven countries launched the EMU; 19 of them now share the same currency, the euro (Zestos \& Benedict, 2018).

Integration has been deepening in Europe since the early 1950s. With the Maastricht Treaty, the EEC was renamed the EU, denoting a higher level of integration. ${ }^{18)}$ Germany was a signatory party on all of these treaties and was part of the North Atlantic Treaty Organization (NATO) ${ }^{19}$ ). As a member of the EU and its predecessor organizations, Germany had no choice but to comply with these organizations' industrial policies. This alignment, however, was not difficult because Germany intervened in its economy less than other countries did, especially in comparison to two other large EU countries, the UK and France. Between 1951 and 1960, Germany attained an annual real economic growth rate of 8.3 percent; this period is referred as the "miracle growth" period. It is no coincidence that Japan also experienced a period of high growth that is referred as miracle growth period.

German industrial policy was rather inactive during this period; it cannot be considered the most important factor in Germany's miracle growth. Competition and trade liberalization are major drivers of economic growth as well. Some characteristics of the German economy are similar to those of Japan's economy. For example, both countries generate high savings rates that are channeled into high domestic investment rates. Moreover, both countries maintain large shares of highly trained and very productive permanent employees.

The theoretical rationale for industrial policy is to correct market failures through, for example, breaking up monopolies, correcting externalities, and assisting firms in entering new markets. ${ }^{20)}$ Industrial policy can help new firms raise large startup costs. From the end of WWII until the early 1980s, several high-tech industries were targeted and supported by EEC member states for the purpose of creating national champions. This support was believed to be necessary because Europe's high-tech industries were lagging behind those of the US. Thus, firms that were selected to succeed were offered a variety of incentives, including the option to form mergers and receive subsidies for their R\&D expenditures. Such preferential treatment of firms was more common in the UK and France than in Germany.

These efforts, however, were often unsuccessful, as it is difficult to select firms that will become national champions (Owen-Smith, 2012). The participation of three European countries was necessary to succeed in establishing a champion in the aerospace industry that could compete against the US aerospace giant, Boeing. This company was named Airbus and was initially launched in 1967 through an agreement between the governments of France, Germany, and the UK. The French company Aérospatialle and the West German company Airbus were the

18) The EU consists of 27 members as of 2021.

19) NATO is a military alliance signed in 1949 that includes 30 countries across both sides of the Atlantic Ocean. Germany joined in 1955.

20) Expanding output beyond domestic production to exports can help firms achieve economies of scale. 
two original partners. Presently, Airbus is one of two companies worldwide that produces commercial jetliners and military airlifters. It produces aircraft in five countries and parts in numerous locations around the world. Airbus would certainly not exist in its current form without the initial multinational consortium that secured funding for leading technology, well-trained engineers, and high-quality management.

In the 1980s, European and national industrial policies drastically changed; countries could no longer target and support certain industries or companies. Industrial policies became horizontal, that is, they promoted competition by improving the overall environment for all firms. Starting in early 1970s, the vast majority of European countries were affected by both high inflation and unemployment. The two oil crises, combined with an aging population and rigid labor laws, had major negative and prolonged impacts that lasted for decades. European leaders at that time felt that Europe was falling behind both the US and Japan and that something had to be done. The response was the Lisbon Treaty in 2000. All EU members accepted the Lisbon Agenda, which included 289 new pieces of legislation, most of which were directives that all EU member countries had to introduce into their national legislations to transform the EU into the most competitive economy worldwide within 10 years. This important treaty affected the economic and industrial policies, among others, of all EU member countries for many years. EU members responded to the Lisbon Agenda by launching fiscal austerity, reducing public deficits and public and private wages, and adopting neoliberal pro-business policies to make their businesses internationally competitive.

Germany responded to the Lisbon Treaty by introducing a sequence of new laws under the SPD government of Chancellor Gerhard Schröeder. These laws are known as the Hartz Reforms. The Hartz Reforms passed many pro-business, anti-labor laws aiming to reduce unemployment by liberalizing the rules for hiring and firing workers and allowing new labor contracts to promote temporary and precarious employment (Evans \& Gibb, 2009; Zestos, 2016).

Industrial policy has been changing over time owing to global competition and the creation of new and more active regional organizations. Current industrial policy includes some activities that were not previously imagined. In 2009, Jörg Meyer-Stamer, a German scholar with interests in competitiveness and economic development, expressed the view that industrial policy must be more broadly defined in an ever-changing world. In addition, he was critical of Germany for comparing unfavorably vis-a-vis a group of industrialized countries in the use of tax incentives to increase innovation, the ratio of venture capital to investment, and the percent of startups with promising opportunities.

Since the 1970s, several developed countries' manufacturing sectors have contracted; this contraction was more evident during the global financial crisis (2007-2009). This phenomenon is known as deindustrialization. Germany was able to weather this crisis much better than most other EU countries did owing to the painful Hartz Reforms that it launched in 2003 to 2005 
in response to the Lisbon Agenda and other labor programs. Germany took advantage of the recent globalization of manufacturing to move production operations abroad with the help of its multinational corporations, which operate in more than 100 countries worldwide. Thus, Germany shifted some its domestic production abroad by at least partially substituting FDI for exports ${ }^{21)}$. Its massive investments, especially in China, allowed Germany to avoid high domestic wages by taking advantage of low Chinese wages and by selling a large share of its products to China and other East Asian countries. At the same time, Germany maintained good relations with its host countries, as it provided employment opportunities to their local economies (Erber, 2016). Furthermore, increasing FDI reduced its trade surpluses with southern Eurozone countries. Germany was criticized for this practice by the EU, the IMF, many economists, and world leaders because it contributed to the global trade imbalances that were a source of global instability (Zestos et al., 2016).

One important difference between Japan and Germany is Germany's relatively recent decision, following the 2016 Fukushima nuclear meltdown, to announce the eventual end of all nuclear and fossil fuel power stations. This decision will provide Germany with clean energy and boost the green economy. In Japan, Prime Minister Abe refused to support shutting down nuclear plants despite popular demand. In Germany, the policy was a top-down decision, which is not the most appropriate approach for any policy. However, Chancellor Merkel's decision had strong support from several grassroot groups and the Green Party, which is becoming increasingly popular.

The decision to cancel nuclear plants is an environmental policy and, thus, may seem to be unrelated to industrial policy, but this claim is incorrect. After Merkel's announcement, pertinent questions regarding industrial policy had to be addressed, such as whether forms of clean energy (e.g., solar and wind power) should be subsidized and, if so, for how long. Germany developed both industries quickly, and other countries followed suit. Once the industries were developed, their subsidies were discontinued, and Germany became a model for other countries.

\section{Data and Variables}

We retrieved trade data for Germany and Japan from three sources: the World Bank, the IMF, and the OECD. To simplify comparisons, key variables for both countries are expressed in terms of 2010 US dollars whenever appropriate. The dependent variable of interest for both countries is real exports, denoted by X. Here, exports are defined by the World Bank as the value of all goods and services provided to the rest of the world. Figure 1 shows Germany's

21) This shift is another striking similarity between Germany and Japan; however, Germany began doing so several years after Japan did. 
and Japan's real exports for the period from 1970 to 2018. During the entire period, both Japanese and German exports almost always increase, except during the global financial crisis in 2008 and 2009. As Figure 1 shows, German exports exceed Japanese exports, and their difference consistently increases over time.

Figure 1. Germany \& Japan exports (In 2010 USD)

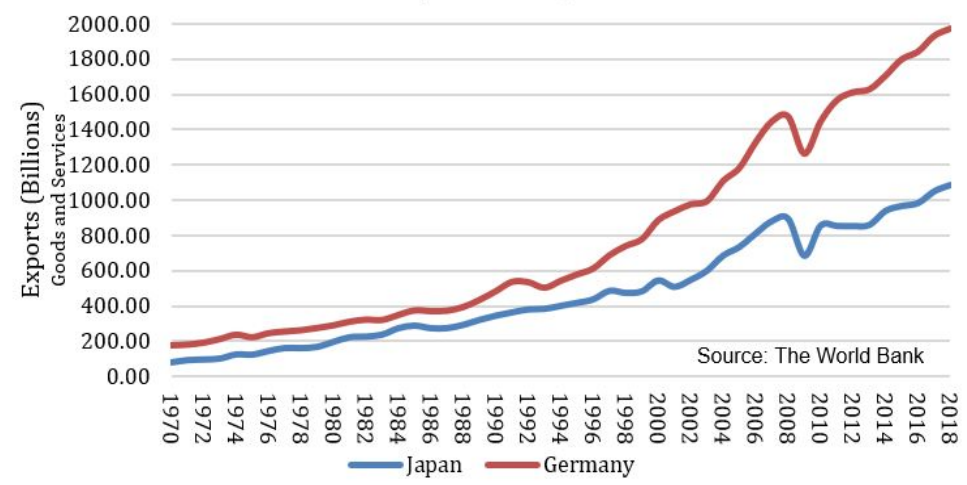

Figure 2 shows the time plots of the real imports of the two countries, denoted by M, for the same period. We again find that German imports exceed Japanese imports. The difference between the two countries' imports has been also increasing over time. Observing the two figures, we can see that the impact of the global financial crisis is again pronounced from 2008 to 2010, as both exports and imports fall sharply.

Figure 2. Germany \& Japan imports (In 2010 USD)

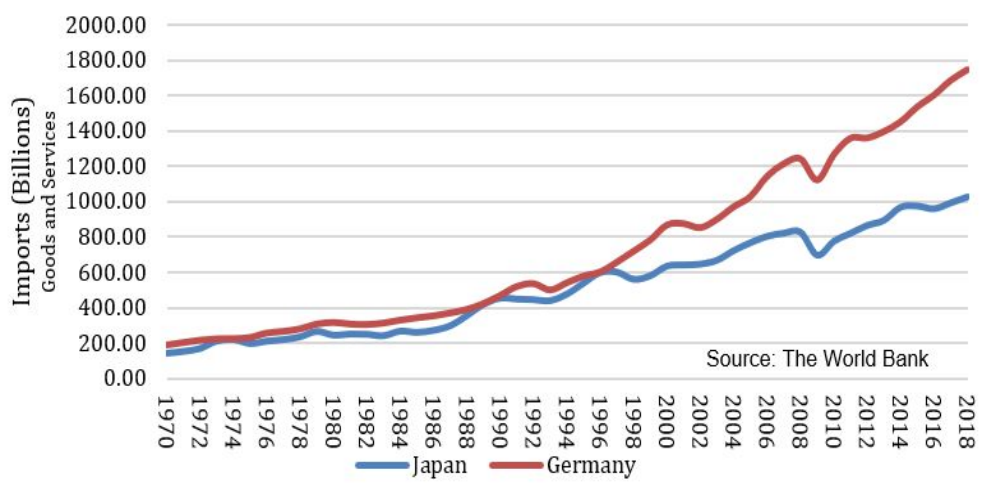


We subtract Japan's or Germany's GDP from real global GDP to create a proxy for the external demand for each country's exports and denote this proxy as $Y_{W}$. We measure international price competitiveness using the real effective ER for Japan and the TOT for Germany ${ }^{22) . ~ J a p a n ' s ~ r e a l ~}$ effective ER is the nominal effective ER index adjusted for relative national price movements or cost indicators 23). The TOT is defined as the ratio of the index of export prices to the index of import prices. The IMF has recently updated these data ${ }^{24)}$. If export prices increase by more than the import prices do, then a country's TOT improves. An improvement in a country's TOT nevertheless implies a loss of international competitiveness because that country's exports become more expensive and its imports become cheaper. Figure 3 shows each country's price competitiveness.

Figure 3. Price competitiveness

(in 2010 USD)

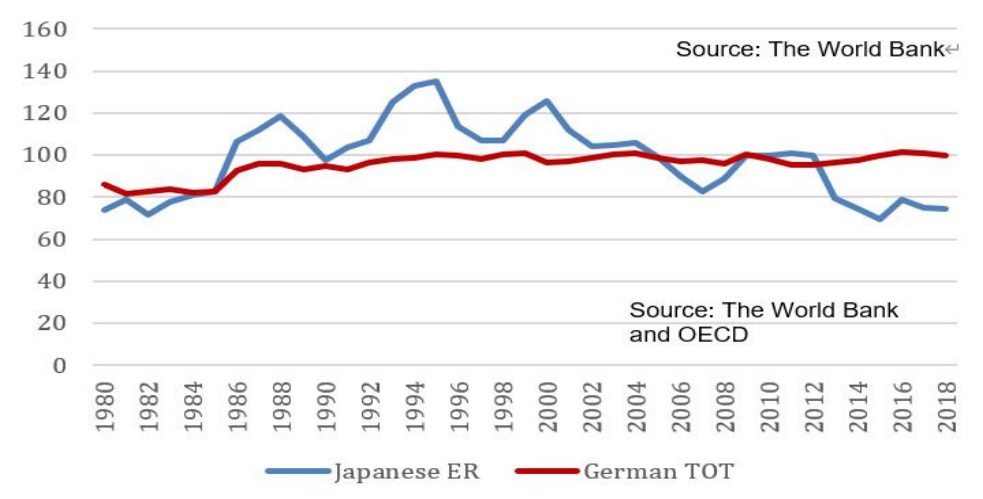

The gap between imports and exports is even more pronounced when we consider the differences in the real GDPs of the two countries. As Figures 1A (real GDP) and 2A (real GDP per capita) in the Appendix show, Germany's real GDP is about two thirds of that of Japan. However, this difference is largely due to Germany's smaller population, as the real GDPs per capita of the two countries are almost equal. Moreover, since the global financial crisis, the gaps between both the exports and imports of the two countries have been increasing. However, the gap between their real GDPs has remained nearly constant for many years. All of this evidence implies that the foreign sector (i.e., exports and imports) accounts for a much larger fraction of GDP in Germany than in Japan. This conclusion is clearly supported by Figure 4, which

22) We choose to use the TOT for Germany because the ER does not pass the unit root test.

23) The nominal effective ER index is the ratio of the index of a currency's period-average ER to a weighted geometric average of the ERs of selected countries' currencies. The index is 100 for the base year of 2010. The construction of these indices is described by Bayoumi and Jayanthi (2006).

24) See https://www.imf.org/en/News/Articles/2019/03/26/pr1993-the-imf-updates-the-effective-exchange-rates-indices 
plots the trade openness, that is, the sum of exports and imports divided by GDP, of the two countries. Germany's trade openness is more than double Japan's trade openness.

Figure 4. Trade openness

(defined as the sum of exports and imports divided by the GDP)

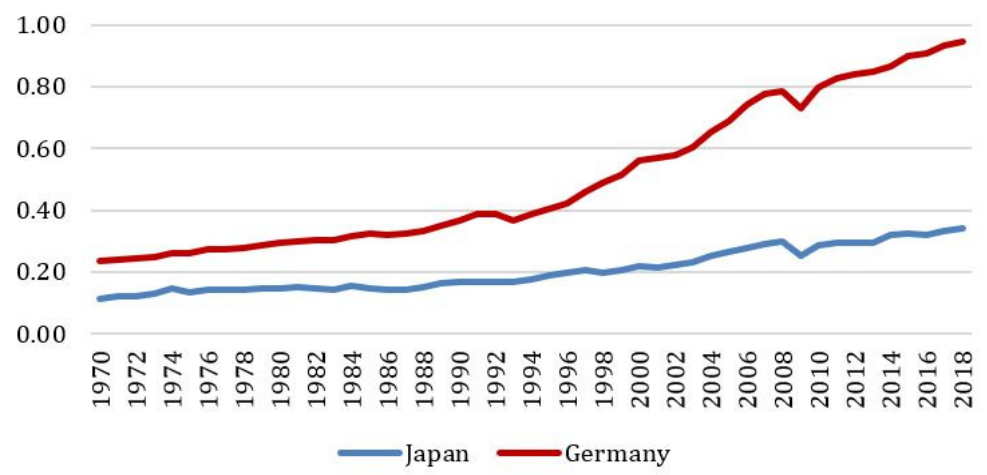

It is not easy to explain why Germany is much more trade-dependent in comparison to Japan, which is known to play a key role in the East Asian and global supply chains. Nevertheless, we try to provide an explanation. Domestic firms, instead of producing goods at home and exporting them, can and do invest abroad and build factories or purchase production facilities in foreign countries. In balance of payments accounts, these business strategies result in changes to FDI25). The export-import patterns of the two countries can be further explained by examining annual outbound flows of FDI, which is presented in Figure 5.

Figure 5. FDI outward flows

(in million dollars)

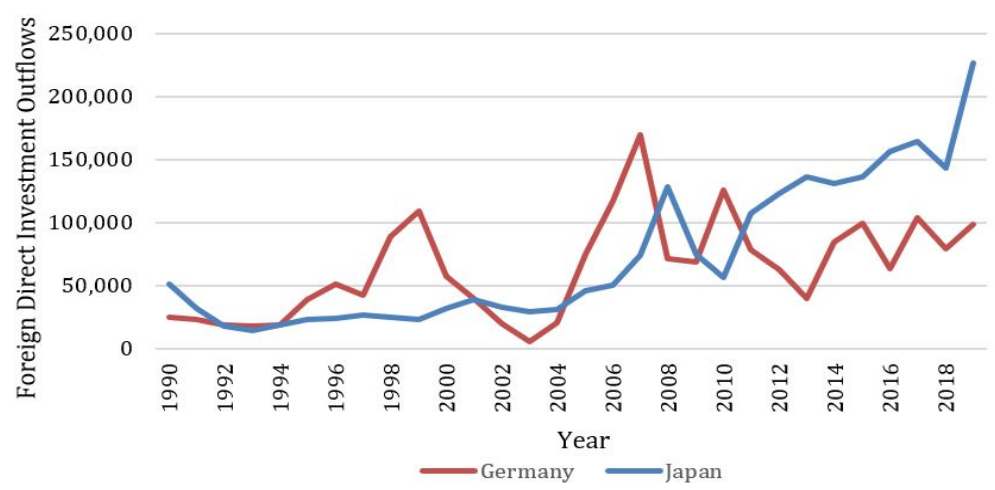

25) FDI is defined as domestic firms building factories abroad or purchasing foreign production facilities and acquiring ownership of at least ten percent of a foreign firm's equity. 
Figure 5 shows that Germany and Japan had similar FDI from 1990 to 2011, although Germany's FDI exceeded Japan's in most years. Starting in 2011, however, Japan's FDI consistently and increasingly exceeded Germany's FDI, which initially declined and more recently leveled off at approximately 100 billion US dollars. The boom in Japanese FDI, which began in 2010, is attributed to a change in Japan's business strategy to avoid trade protectionism (e.g., tariffs) from the US, its most important trading partner historically. Because FDI is a substitute for exports, a rise in Japanese FDI reduced exports and, thus, tended to restrain the Japanese economy. Fukao (2013) also suggests that the increase in outward FDI from Japan negatively impacted the Japanese economy's performance, as small and medium-sized enterprises (SMEs) lack the advanced technologies that are available to large Japanese firms abroad. This situation is the exact opposite of that in Germany, as SMEs play a dominant role in the German economy.

\section{Methodology}

\section{A. Causality and cointegration}

For the last half century, new methodologies have been developed to explain the causal relationships among economic variables beyond the level of statistical correlation. These methods have led to a substantial body of research involving time series variables. In this study, we aim is to test the causal relations ${ }^{26)}$ among exports and related macroeconomic variables.

A relationship can be falsely detected when the variables included in a model are nonstationary of different orders. To avoid this so-called spurious regression problem, it is important to examine the dynamic properties of the variables in a model before testing for evidence of cointegration. Johansen $(1991,1995)$ extends the test for cointegration from a bivariate model to a multivariate system of equations. Such tests, however, require all of the included variables to be stationary in their first differences, or I(1). Once cointegration is established with the Johansen methodology, Granger causality tests can be performed using the estimated VECM. A one-period lagged error correction term $\left(\mathrm{EC}_{\mathrm{t}-1}\right)$ is constructed according to the cointegrating equation and is included as an additional variable on the right-hand side of the VECM. The coefficient of $\mathrm{EC}_{\mathrm{t}-1}$ indicates not only the strength of the causality but also the speed at which the variables converge to their long run equilibrium values.

This study employs the ARDL model developed by Pesaran et al. (2001) to test for evidence of cointegration. This method is a major milestone in cointegration testing because it allows for

26) The study of econometric causality originated with the seminal work of Granger (1969), who focused on the causal relationships between two time series variables. The concept of Granger causality is now widely applied across other branches of economics and disciplines. In 1987, Granger and his colleague Robert Engle introduced the concept of cointegration, another major econometric contribution that earned them the Nobel Prize in economics. 
the inclusion of a mixture of $\mathrm{I}(0)$ and $\mathrm{I}(1)$ variables. In other words, this method is valid as long as no variables are $\mathrm{I}(2)$ or above. In this sense, it is more flexible than the Johansen method, which requires all variables to be I(1). Once cointegration is established with the ARDL model, we use the Toda-Yamamoto (1995) vector autoregressive (VAR) model to test for Granger causality.

Before estimating the ARDL model, the dynamic properties of all included variables must be tested. Four different unit root tests are performed to make sure that all included variables meet the requirements of the ARDL model. We perform the two unit root tests that are most commonly employed by economists, the augmented Dickey-Fuller (ADF) and Phillips-Perron (PP) tests (Dickey \& Fuller, 1979; Phillips \& Perron, 1988)27). We also perform two additional unit root tests: The Dickey-Fuller generalized least squares test, created by Elliot et al. (1996), and the Ng-Perron test ( $\mathrm{Ng} \&$ Perron, 2001). According to these tests, a few variables are stationary in levels, that is, $\mathrm{I}(0)$, and the other variables are stationary in their first differences, or I(1). Furthermore, no variables are stationary in second differences, that is, I(2), or beyond. Consequently, the only correct model with the Japanese and German data is the ARDL model.

\section{B. ARDL model}

The ARDL model is a single equation model of which the dependent variable is expressed in levels. In this model for both Japan and Germany, the dependent variable is the natural logarithm of real exports. The models use the lagged values of exports as well as imports, foreign demand, and international competitiveness to determine the present value of exports ${ }^{28)}$. We present the ARDL models for both Japan and Germany. Because data on the ER and the TOT are not available for the 1970s, we restrict the sampling period to 1980 to 2018 for Japan and 1979 to 2018 for Germany.

The Japanese model includes four variables in real terms, expressed in natural logarithms. These variables are real exports $\left(\ln \mathrm{X}_{\mathrm{t}}\right)$, real global GDP $\left(\ln \mathrm{Y}_{\mathrm{Wt}}\right)$, the ER $\left(\operatorname{lnER} \mathrm{R}_{\mathrm{t}}\right)$, and real imports $\left(\operatorname{lnM}_{t}\right)^{29)}$. Equation (1) represents the ARDL model for the Japanese economy.

$$
\begin{aligned}
\Delta \ln X_{t}= & \alpha_{0}+\alpha_{1} T+\alpha_{2} \ln X_{t-1}+\alpha_{3} \ln Y w_{t-1}+\alpha_{4} \ln E R_{t-1}+a_{5} \ln M_{t-1}+ \\
& \sum_{i=1}^{r} \alpha_{1 i} \Delta \ln X_{t-i}+\sum_{i=0}^{s} \alpha_{2 i} \Delta \ln Y w_{t-i}+\sum_{i=0}^{k} \alpha_{3 i} \Delta \ln E R_{t-i}+ \\
& \sum_{i=0}^{p} \alpha_{4 i} \Delta \ln M_{t-i}+\epsilon_{t}
\end{aligned}
$$

The model includes a constant, denoted by $\alpha_{0}$; a trend variable, denoted by $T$; and the one-

27) The ADF and PP unit root tests are criticized for too often rejecting correct null hypotheses and failing to reject false null hypotheses (Alimi, 2014; DeJong et al., 1992).

28) This relationship has been documented by numerous studies, such as those of Stahn (2006), Thorbecke and Kato (2012a, 2012b), and Bahmani-Oskooee and Mohammadian (2017).

29) Because all variables are defined in real terms, we omit the word "real" henceforth. 
period lagged values of all variables, denoted by $\ln X_{t-1}, \ln Y_{W_{t-1}}, \ln E R_{t-1}$, and $\ln M_{t-1}$. It also includes the lagged differences of all variables of orders $r, s, k$, and $p$. The optimal numbers of lags are determined according to the Akaike information criterion (AIC). The parameters to be estimated are $\alpha_{0}, \alpha_{1}, a_{2}, \alpha_{3}, \alpha_{4}, \alpha_{5}, \alpha_{1 i} . \alpha_{2 i}, \alpha_{3 i}$, and $\alpha_{4 i}$. The test for cointegration in an ARDL model is called the Bounds Test, introduced by Pesaran et al. (2001). It is essentially a Wald F-test of the joint significance of all of the coefficients of the one-period lagged variables:

$\mathrm{H}_{0}: a_{2}=\alpha_{3}=\alpha_{4}=\alpha_{5}=0$ (no cointegration); $\mathrm{H}_{\mathrm{a}}$ : at least one of the $\alpha_{i} \neq 0$, where $i=2,3,4.5$.

Equation (2) describes the ARDL model for Germany:

$$
\begin{aligned}
\Delta \ln X_{t}= & \beta_{0}+\beta_{1} T+\beta_{2} \ln X_{t-1}+\beta_{3} \ln Y w_{t-1}+\beta_{4} \ln T O T_{t-1}+\beta_{5} \ln M_{t-1}+ \\
& \sum_{i=1}^{r} \beta_{1 i} \Delta \ln X_{t-i}+\sum_{i=0}^{s} \beta_{2 i} \Delta \ln Y w_{t-i}+\sum_{i=0}^{k} \beta_{3 i} \ln \Delta T O T_{t-1}+ \\
& \sum_{i=0}^{p} \beta_{4 i} \ln \Delta M_{t-i}+\epsilon_{t}
\end{aligned}
$$

Similarly, the Bounds Test for cointegration can be stated in terms of the $\beta$ coefficients. $\mathrm{H}_{0}$ is that $\beta_{2}=\beta_{3}=\beta_{4}=\beta_{5}=0$ (no cointegration), and $\mathrm{H}_{\mathrm{a}}$ is that at least one of the $\beta_{i} \neq 0$, where $i=2,3,4,5$. In both models, $t$ is a time index ranging from 1 to 39 for Japan and 1 to 40 for Germany.

Note that in the Japanese model, we use the natural log of the real ER (lnER) as a proxy for the price competitiveness of exports. Because lnER does not meet the necessary conditions to be used in the ARDL German model, we use the natural logarithm of the TOT (InTOT), another popular proxy for price competitiveness. Both models proxy foreign demand using the difference between global GDP and the focal country's GDP $\left(\ln Y_{w}\right)$. Both models also include real imports $(\operatorname{lnM})$ on the right-hand side. Many economists support the view that countries' exports and imports are closely related. The interdependence of exports and imports can be explained easily for the vast majority of countries because, in the long run, countries can only pay for imports with the earned revenue from exports. Historical statistics for Japanese and German exports and imports indicate that both counties have generated prolonged trade imbalances. Japan has generated a sequence of trade deficits as well as a few surpluses. ${ }^{30}$ ) Nevertheless, since 2000, Germany has generated only increasing trade surpluses and, thus, has been consistently criticized by economists and policy circles for destabilizing the global economy. ${ }^{31)}$

30) See Figure 4 in the Appendix for a comparison of trade balances.

31) This is a major issue for the EU and the world economy (Zestos et al., 2016). 
To facilitate comparisons, all of the empirical findings of the two models are presented in side-by-side tables. The estimated Japanese model is shown on the left side of each table, and the estimated German model is reported on the right side of each table.

\section{Empirical Findings}

\section{A. ARDL models and bounds tests}

Table 1 presents the estimated ARDL models for the two countries. The dependent variable and the three independent variables are shown for each model in the top two rows of the table. The numbers in parentheses indicate the number of lagged values of the dependent and independent variables in the order in which the independent variables appear below the dependent variable. Specifically, for the Japanese model, the numbers $(3,3,1,0)$ mean that three lagged values are selected for $\ln \mathrm{X}_{\mathrm{t}}$ and $\ln Y_{w_{t}}$, one lagged value is selected for $\operatorname{lnER} \mathrm{t}$, and none are selected for $\operatorname{lnM}_{\mathrm{t}}$. For the German model, the numbers $(2,1,0,2)$ mean that the model chose two lagged values for $\ln \mathrm{X}_{\mathrm{t}}$, one lagged value for $\ln Y_{w_{t}}$, no lagged values for InTOT, and two lagged values for

Table 1. Estimated Unrestricted ARDL Japanese and German Models

\begin{tabular}{|c|c|c|c|}
\hline \multicolumn{2}{|c|}{$\begin{array}{c}\text { Japan Model }(3,3,1,0) \\
1980-2018\end{array}$} & \multicolumn{2}{|c|}{$\begin{array}{c}\text { German Model }(2,1,0,2) \\
1979-2018\end{array}$} \\
\hline Dependent Variable & $\ln X$ & Dependent Variable & $\ln X$ \\
\hline Independent Variables & $\ln Y_{\mathrm{Wt}}, \ln E R_{\mathrm{t}}, \ln \mathrm{M}_{\mathrm{t}}$ & Independent Variables & $\ln \mathrm{Y}_{\mathrm{Wt}}, \ln \mathrm{TOT}_{\mathrm{t}}, \ln \mathrm{M}_{\mathrm{t}}$ \\
\hline $\mathrm{C}$ & $-44.29 * * *$ & $\mathrm{C}$ & $-22.03 * * *$ \\
\hline Trend & $-0.04 * * *$ & Trend & $-0.02 * * *$ \\
\hline $\ln X_{t-1}$ & $0.51 * * *$ & $\ln X_{t-1}$ & $0.63^{* * *}$ \\
\hline $\ln \mathrm{X}_{\mathrm{t}-2}$ & $0.36^{*}$ & $\ln X_{t-2}$ & $-0.23 *$ \\
\hline $\ln \mathrm{X}_{\mathrm{t}-3}$ & $-0.23 * *$ & & \\
\hline $\ln Y_{W t}$ & $4.19 * * *$ & $\ln Y_{\mathrm{Wt}}$ & $1.66^{* * *}$ \\
\hline $\ln Y_{\mathrm{Wt}-1}$ & $-3.47 * *$ & $\ln Y_{\mathrm{Wt}-1}$ & $-0.96 * * *$ \\
\hline $\ln Y_{\mathrm{Wt}-2}$ & -2.10 & $\operatorname{lnTOT}$ & $-0.37 * * *$ \\
\hline $\ln Y_{\mathrm{Wt}-3}$ & $2.77 * * *$ & $\ln M_{t}$ & $0.81 * * *$ \\
\hline $\operatorname{lnER}_{\mathrm{t}}$ & -0.07 & $\ln \mathrm{M}_{\mathrm{t}-1}$ & $-0.48^{* *}$ \\
\hline $\operatorname{lnER}_{\mathrm{t}-1}$ & -0.12 & $\ln \mathrm{M}_{\mathrm{t}-2}$ & $0.35^{* *}$ \\
\hline $\ln M_{t}$ & $0.45^{* * *}$ & & \\
\hline Break10 & 0.06 & Break 93 & -0.00 \\
\hline $\mathrm{R}^{2}$ & 0.99 & $\mathrm{R}^{2}$ & 0.99 \\
\hline$\overline{R^{2}}$ & 0.99 & $\overline{R^{2}}$ & 0.99 \\
\hline DW & 2.03 & DW & 2.30 \\
\hline
\end{tabular}


$\ln \mathrm{M}_{\mathrm{t}}$. The numbers of lags selected suggest that the Japanese model has a longer memory in extracting information from the past values of the dependent and independent variables.

The most important factor affecting $\ln \mathrm{X}_{\mathrm{t}}$ in both the Japanese and German models is external demand, which is proxied by global GDP $\left(\ln \mathrm{Y}_{\mathrm{Wt}}\right)$. Four terms of $\ln \mathrm{Y}_{\mathrm{Wt}}$ enter the estimated equation of the Japanese ARDL model, including the contemporaneous term $\ln \mathrm{Y}_{\mathrm{Wt}}$, and three orders of lagged terms. In the German model, however, only the first two terms, $\ln Y_{\mathrm{Wt}}$ and $\ln \mathrm{Y}_{\mathrm{Wt}-1}$, are included on the right-hand side of the model. In both models, all of the included lags of the dependent variable, $\ln \mathrm{X}_{\mathrm{t}}$, of the first, second, and third order are significant. This finding suggests that historical export performance continues to affect present exports.

In the German model, contemporaneous imports $\left(\operatorname{lnM}_{t},\right)$ and its first two lagged terms, $\ln \mathrm{M}_{\mathrm{t}-1}$ and $\operatorname{lnM}_{t-2}$, also have strong impacts on exports. In contrast, only $\ln _{t}$ is included in the Japanese model, but it is highly statistically significant. As expected, the positive coefficients of $\ln M_{t}$ in both models indicate a strong positive relation with $\ln \mathrm{X}_{\mathrm{t}}$. Furthermore, both coefficients are highly significant at the one percent level. Looking at the effects of international competitiveness on exports, in the Japanese model, two ER terms, $\operatorname{lnER}_{t}$ and $\operatorname{lnER}_{t-1}$, are included on the right-hand side of the equation, but both terms have insignificant effects. Finally, only the contemporaneous TOT (lnTOT) appears in the German model, but it is negative and highly significant at the one percent level, as is theoretically expected.

To improve the goodness of fit of the two models, we include a structural break in each model. The breaks indicate years in which changes in economic activity occurred. In the Japanese model, we include a break in 2010, which corresponds to the end of the global financial crisis. In the German model, we include a break in 1993, corresponding to the recession in Germany in the first phase of its unification after the collapse of the Berlin Wall. The structural breaks enter into in the model as dummy variables equal to one for 2010 and 1993 and zero for all other years for both countries.

In Table 132), several statistics of the estimated ARDL models are also reported to evaluate their quality. The overall fitness of the two models, as indicated by $\mathrm{R}^{2}$ and $\overline{R^{2}}$, is very high. To ensure that both models are free from serial correlation, we perform the Lagrange multiplier Breush-Godfrey test and report the results in Table 2. Both ARDL models pass the test for no serial correlation at the five percent significance level.

32) Another version of the estimated ARDL models shown in Table 1 is presented in Table 1C of the Appendix. This table essentially reports the same model, but its format is similar to the theoretical ARDL model of equation (1). The constant, the trend, and the break coefficients are identical to those reported in Table 1. Although it looks different, the rest of Table $1 \mathrm{C}$ is the same as the results reported in Table 1. It begins with one-period lagged variables $\ln X_{t-1}, \quad \ln Y_{W_{t-1}}, \quad \ln E R_{t-1}, \quad \ln M_{t-1}$ and continues with the sums of the four lagged difference terms, as in the ARDL model given by equation (1). 
Table 2. Breusch-Godfrey Serial Correlation LM Test

\begin{tabular}{ccc}
\hline & & $\chi^{2}$ Test \\
\cline { 2 - 3 } Lags & $\begin{array}{c}\text { Japan Model } \\
\text { p-values }\end{array}$ & $\begin{array}{c}\text { Germany Model } \\
\text { p-values }\end{array}$ \\
\hline 1 & 0.8014 & 0.0708 \\
2 & 0.8311 & 0.1678 \\
3 & 0.7328 & 0.1707 \\
4 & 0.3633 & 0.0633 \\
\hline
\end{tabular}

Table 3 reports the results of the Bounds Test for cointegration. The calculated Wald F-statistic is compared with two sets of critical values ${ }^{33}$ ). The lower limits (bounds) are calculated for the case in which all time series are $\mathrm{I}(0)$. The upper limits are calculated assuming that all variables are I(1). If the calculated F-statistic falls below the lower limit (bound), then the test fails to reject the null hypothesis of no cointegration. If the calculated F-statistic exceeds the upper limit of the asymptotic distribution, then the test rejects the null hypothesis of no cointegration. The test is inconclusive if the F-statistic falls within the upper and lower limits.

Table 3. Cointegration: Bounds Tests

\begin{tabular}{|c|c|c|c|c|}
\hline \multirow{2}{*}{ Significance Level } & \multicolumn{2}{|c|}{ Japan: $n=39, d f=3$} & \multicolumn{2}{|c|}{ Germany: $n=40, d f=3$} \\
\hline & $\mathrm{I}(0)$ Bound & I(1) Bound & $\mathrm{I}(0)$ Bound & I(1) Bound \\
\hline $10 \%$ & 3.80 & 4.88 & 2.96 & 4.10 \\
\hline $5 \%$ & 4.56 & 5.79 & 3.62 & 4.91 \\
\hline $1 \%$ & 6.36 & 7.73 & 5.20 & 6.85 \\
\hline F-statistics & \multicolumn{2}{|c|}{$14.25 * * *$} & \multicolumn{2}{|c|}{$15.53 * * *$} \\
\hline
\end{tabular}

The calculated value of the F-statistic for Japan is 14.25, and that for Germany is 15.53; both values reject the null hypothesis of no cointegration at any conceivable level significance. Another useful feature of the estimated ARDL model is that it generates a cointegrating equation. This equation shows the a long-run linear relationships among the variables in the ARDL model. We present the cointegrating equations of the Japanese and German models in the next section.

\section{B. Estimated cointegration equations}

\section{Cointegration equation for Japan}

Equation (1)' is the cointegrating equation for Japan.

$$
\begin{array}{cccc}
\ln \mathrm{X}_{\mathrm{t}}= & 3.84 \ln \mathrm{Yw}_{\mathrm{t}} & -0.51 \operatorname{lnER} R_{\mathrm{t}} & +1.23 \operatorname{lnM}_{\mathrm{t}} \\
\mathrm{p} \text {-value } & (0.00) & (0.04) & (0.00)
\end{array}
$$

33) These values are derived by Pesaran et al. (2001) for large samples. 
Because all of the variables are expressed in terms of logarithms, the coefficient of each variable is the elasticity of exports with respect to that particular variable. The elasticity of exports with respect to global GDP, for example, is $\mathrm{E}_{\mathrm{XYw}}=3.84$. This number indicates that a one-percent increase in global income leads to an increase in demand for Japanese exports of 3.84 percent, which is a relatively large response. This result can nevertheless be justified because many Japanese exports are high-tech consumer goods, such as electronics and automobiles, which are luxury goods.

The elasticity of exports with respect to the ER $\left(\mathrm{E}_{\mathrm{XER}}=-0.51\right)$ is rather low, indicating that an increase in the ER implies a one-percent increase in the price of Japanese exports reduces Japanese exports by about half of one percent. This rather weak response can be explained by the fact that Japanese exports did not have many close substitutes during the sample period. Hooper et al. (1998) and Jiang et al. (2020) also find a weak link between the ER and exports of this magnitude. Fukuda and Doita (2016) echo this finding, as the fixed costs associated with shifting plants' location to other countries have made Japanese exports immune to changes in the ER.

Finally, the elasticity of exports with respect to imports is $\mathrm{E}_{\mathrm{X} . \mathrm{M}}=1.23$. This result indicates that imports are crucial factor in the level of exports. If, for example, imports increase by one percent, then Japanese exports increase by 1.2 percent.

\section{Cointegrating equation for Germany}

Equation $2^{\prime}$ is the cointegrating equation for Germany based on the ARDL model.

$$
\begin{array}{cccc}
\ln \mathrm{X}_{\mathrm{t}}= & 1.17 \ln \mathrm{Yw}_{\mathrm{t}}- & 0.62 \ln \mathrm{TOT}_{\mathrm{t}}+ & 1.12 \operatorname{lnM}_{\mathrm{t}} \\
\mathrm{p} \text {-value } & (0.00) & (0.00) & (0.00)
\end{array}
$$

The elasticity of exports with respect to global GDP is $\mathrm{E}_{\mathrm{XYw}}=1.17$. This elasticity is small compared to the corresponding Japanese elasticity. One possible explanation for this asymmetry is that buyers of German exports choose not to increase their demand beyond a certain point, either because demand is satiated or because German goods have high prices.

The elasticity of German exports with respect to the TOT $\left(\mathrm{E}_{\text {Xтот }}=-0.62\right)$ is close to the Japanese elasticity with respect to the ER. This result indicates that the demand for exports is not very responsive to changes in their relative price. Finally, the elasticity of exports with respect to imports $\left(\mathrm{E}_{\mathrm{XM}}\right)$ is 1.12. This value is almost identical to that for Japan. The two countries' large export sectors are supported by imports. In the early stages of economic development, especially after WWII, most imports were machinery and equipment, and Japan and Germany have always imported raw materials and energy. Nevertheless, for many years after their economies were rebuilt following WWII, both countries were exporters of not only high-tech capital goods, such as machinery 
and equipment, but also of high-quality consumer goods, such as vehicles and electronics (Van Ark et al., 1993).

However, with increased globalization, both Japan and Germany are relying on large quantities of imported components from countries that have developed comparative advantages by specializing in the production of such components. This reliance became evident recently when the international production supply chain was disrupted owing to COVID-19. Japan and Germany have continued to import raw materials and energy. Both countries are known to experience scarcities in these goods and, thus, rely heavily on imports.34)

Table 4. Estimated Long Run ECM of the ARDL Models for Japan and Germany

\begin{tabular}{|c|c|c|c|}
\hline \multicolumn{2}{|c|}{ Japan Model $(3,3,1,0)$} & \multicolumn{2}{|c|}{ Germany Model $(2,1,0,2)$} \\
\hline Dependent Variable & $\ln X_{t}$ & Dependent Variable & $\ln X_{t}$ \\
\hline Independent Variables & $\ln Y_{W t}, \operatorname{lnER} R_{t}, \ln M_{t}$ & Independent Variables & $\ln \mathrm{Y}_{\mathrm{Wt}}, \ln \mathrm{TOT}_{\mathrm{t}}, \ln \mathrm{M}_{\mathrm{t}}$ \\
\hline $\mathrm{C}$ & $-44.29 * * *$ & $\mathrm{C}$ & $-22.32 * * *$ \\
\hline Trend & $-0.05^{* * *}$ & Trend & $-0.02 * * *$ \\
\hline$\Delta \ln X_{t-1}$ & -0.13 & $\Delta \ln \mathrm{X}_{\mathrm{t}-1}$ & $0.23 * *$ \\
\hline$\Delta \ln X_{t-2}$ & $0.22 * *$ & & \\
\hline$\Delta \ln Y_{\mathrm{Wt}}$ & $4.19^{* * *}$ & $\Delta \ln Y_{\mathrm{Wt}}$ & $1.16^{* * *}$ \\
\hline$\Delta \ln \mathrm{Y}_{\mathrm{Wt}-1}$ & 0.67 & $\Delta \ln \mathrm{M}_{\mathrm{t}}$ & $0.81 * * *$ \\
\hline$\Delta \ln \mathrm{Y}_{\mathrm{Wt}-2}$ & $-2.77 * * *$ & $\Delta \ln \mathrm{M}_{\mathrm{t}-1}$ & $-0.34 * * *$ \\
\hline$\Delta \operatorname{lnER_{\mathrm {t}}}$ & -0.06 & & \\
\hline Break10 & 0.06 & Break93 & 0.00 \\
\hline $\mathrm{EC}_{\mathrm{t}-1}$ & $-0.36 * * *$ & $\mathrm{EC}_{\mathrm{t}-1}$ & $-0.60 * * *$ \\
\hline$R^{2}$ & 0.93 & $R^{2}$ & 0.91 \\
\hline$\overline{R^{2}}$ & 0.90 & $\overline{R^{2}}$ & 0.89 \\
\hline S.E. & 0.02 & S.E. & 0.02 \\
\hline D.W. & 2.03 & D.W. & 2.30 \\
\hline SIC & -6.36 & SIC & -6.18 \\
\hline
\end{tabular}

Table 4 reports the estimated long-run error correction model (ECM), which is another representation of the estimated ARDL model. The estimated parameter coefficient values for the constant, the trend, and the break are the same for the ECM and the model in Table 1. In addition, the ECM includes the one-period lagged error term $\left(\mathrm{EC}_{\mathrm{t}-1}\right)$ of the cointegrating equations as an independent variable. $\left.{ }^{35}\right) \mathrm{EC}_{\mathrm{t}-1}$ measures the speed at which the coefficients of the cointegrating equation adjust to their long-run equilibrium values if they happen to deviate

34) These dependencies on imports makes the two countries vulnerable to possible trade blockades, trade wars, or any other disruptions to world trade.

35) This version of the ARDL model is similar to the VECM. The main difference is that the ARDL model consists of a single equation, whereas the VECM is a system of simultaneous equations. 
from these values. If the coefficient of $\mathrm{EC}_{\mathrm{t}-1}$ is large and negative, then the coefficients adjust quickly, which is a desirable feature of the model. The estimated coefficients of $\mathrm{EC}_{\mathrm{t}-1}$ for the Japanese and German ARDL models are -0.36 and -0.60 , respectively. This result implies that 36 and 60 percent of the adjustments of the cointegration coefficients occur within one year for the Japanese and German models, respectively. Thus, both models are reliable.

\section{Granger causality tests}

The evidence of cointegration in both models using the Bounds Tests allows us to test for Granger causality. We use Toda and Yamamoto's (1995) method to perform the Granger causality tests. They show that a VAR model can be used to perform Granger causality tests because the standard asymptotic theory applies. Time series variables of different orders of integration can be used in the model as long as the order of integration does not exceed the length of the VAR model.36) Thus, we test for Granger causality in both models from the three right-hand side variables to the dependent variable, $\ln \mathrm{X}_{\mathrm{t}}$. We estimate the two VAR models for Japan and Germany in the levels of the variables using three lags.

The two estimated VAR models are reported in the Appendix. Both models are estimated using the same data as those employed to estimate the ARDL models. Similarly, both models include structural breaks in the same years as in the corresponding estimated ARDL models ${ }^{37}$ ). Table 5A reports the results of the Granger causality test for Japan, which is called the block exogeneity test and is a Wald test. We program and perform four such tests with EViews, one for each of the four endogenous variables, $\ln X_{t}, \ln \operatorname{lw}_{t}, \operatorname{lnER} t$, and $\operatorname{lnM}_{t}$. The first test checks for Granger causality from the three right-hand side variables, $\ln \mathrm{Fw}_{\mathrm{t}}, \operatorname{lnER} \mathrm{t}$, and $\ln \mathrm{M}_{\mathrm{t}}$, to the left-hand side variable, $\ln \mathrm{X}_{\mathrm{t}}$. We use a $\chi^{2}$ distribution to test for Granger causality based on the joint significance of the coefficients of the three right-hand side variables on $\ln \mathrm{X}_{\mathrm{t}}$. The results reported on Table $5 \mathrm{~A}$ provide strong statistical evidence that $\ln Y_{w_{t}}, \ln E \mathrm{R}_{\mathrm{t}}$, and $\ln _{\mathrm{t}}$ Granger cause Japanese exports at the five percent level of significance (the p-value is equal to .0246). We also perform separate Granger causality tests for each individual variable using t-tests. Global GDP $\left(\operatorname{lnYw}_{t}\right)$ is the only highly significant variable, with a p-value equal to 0.0169. The other three joint significance tests provide evidence of Granger causality in the model except when global GDP $\left(\ln Y_{w_{t}}\right)$ is the left-hand side variable. This result is nevertheless plausible because Japan is a relatively small economy and cannot affect global GDP alone.

36) Length of the model refers to the number of lags included in the VAR model.

37) The two VAR models were found to be free of serial correlation according to the Breusch-Godfrey Serial Correlation LM Test at the 5 percent level of significance. The results of the serial correlation test are reported in Table 3A and $3 \mathrm{~B}$ in the Appendix for Japan and Germany, respectively. The two VAR models were also tested for structural stability using the pictorial inverse unit roots test constructed by EViews. The two VAR models pass the test for structural stability as the inverse roots of the autoregressive polynomials remain within the unit circle; the graphical results of the dynamic structural stability of the two models are reported in the appendix as Figures $3 \mathrm{~A}$. 
Table 5A. Granger Causality Tests within the Estimated VAR Model for $\ln X_{t}$ (Japan)

\begin{tabular}{|c|c|c|c|c|c|c|c|}
\hline Excluded & $\chi^{2}$ & $d f$ & Probability & Exclud & $\chi^{2}$ & $d f$ & Probability \\
\hline \multicolumn{2}{|c|}{ Dependent Variable } & \multicolumn{2}{|c|}{$\ln X_{t}$} & \multicolumn{2}{|c|}{ Dependent Variable } & \multicolumn{2}{|c|}{$\ln \mathrm{Yw}_{\mathrm{t}}$} \\
\hline $\operatorname{lnER} R_{t}$ & 2.858228 & 3 & 0.4140 & $\operatorname{lnER} t$ & 1.031273 & 3 & 0.7937 \\
\hline $\ln \mathrm{Yw}_{\mathrm{t}}$ & 10.20313 & 3 & 0.0169 & $\ln X_{t}$ & 5.455231 & 3 & 0.1413 \\
\hline $\ln M_{t}$ & 0.909628 & 3 & 0.8331 & $\ln \mathrm{M}_{\mathrm{t}}$ & 2.298153 & 3 & 0.5129 \\
\hline All & 19.07642 & 9 & 0.0246 & All & 10.26921 & 9 & 0.3291 \\
\hline \multicolumn{2}{|c|}{ Dependent Variable } & \multicolumn{2}{|c|}{$\operatorname{lnER}_{\mathrm{t}}$} & \multicolumn{2}{|c|}{ Dependent Variable } & \multicolumn{2}{|c|}{$\ln M_{t}$} \\
\hline $\ln X_{t}$ & .838530 & 3 & 0.8402 & $\ln X_{t}$ & 5.680816 & 3 & 0.1282 \\
\hline $\ln \mathrm{Yw}_{\mathrm{t}}$ & 1.029998 & 3 & 0.7940 & $\ln \mathrm{Yw}_{\mathrm{t}}$ & 14.22692 & 3 & 0.0026 \\
\hline $\ln M_{t}$ & 5.755369 & 3 & 0.1241 & $\operatorname{lnER} t$ & 6.225098 & 3 & 0.1912 \\
\hline All & 18.29128 & 9 & 0.0329 & All & 25.01886 & 9 & 0.0030 \\
\hline
\end{tabular}

Note: The VAR model is estimated with three lagged differences.

Table 5B reports the Granger causality test for Germany. We test for joint significance from $\ln \mathrm{Yw}_{\mathrm{t}}, \ln \mathrm{TOT}_{\mathrm{t}}$, and $\ln \mathrm{M}_{\mathrm{t}}$ on $\ln \mathrm{X}_{\mathrm{t}}$ based on the $\chi^{2}$ distribution. The results are stronger for the German model than for the Japanese model. Granger causality is supported at any conceivable level of significance, as the p-value is 0.0064 , whereas it is 0.02 for the Japanese model. In the individual tests, two variables, $\ln \mathrm{Yw}_{\mathrm{t}}$ and $\operatorname{lnTOTt}$, are significant at the five percent level, implying that they Granger cause $\ln \mathrm{X}_{\mathrm{t}}$. This finding is consistent with those of several studies in the literature. The remaining Granger causality tests for joint significance on the remaining three variables statistically support Granger causality for every variable, even when the left-hand side variable is global GDP $\left(\ln \mathrm{Yw}_{\mathrm{t}}\right)$. This empirical finding is likely to arise because Germany's trade sector is twice as large as that of Japan. Thus, changes in Germany do affect the global economy. This finding is an asymmetry between the Japanese and German models.

Table 5B. Granger Causality Tests within the Estimated VAR Model for $\ln X_{t}$ (Germany)

\begin{tabular}{|c|c|c|c|c|c|c|c|}
\hline Excluded & $\chi^{2}$ & $d f$ & Probability & Excluded & $\chi^{2}$ & $d f$ & Probability \\
\hline \multicolumn{2}{|c|}{ Dependent Variable } & \multicolumn{2}{|c|}{$\ln X_{t}$} & \multicolumn{2}{|c|}{ Dependent Variable } & \multicolumn{2}{|c|}{$\ln \mathrm{Yw}_{\mathrm{t}}$} \\
\hline $\ln \mathrm{Yw}_{\mathrm{t}}$ & 8.302475 & 3 & 0.0402 & $\ln X_{t}$ & 4.11626 & 3 & 0.2495 \\
\hline $\operatorname{lnTOT}_{t}$ & 11.16997 & 3 & 0.0108 & $\operatorname{lnTOT} T_{t}$ & 2.875380 & 3 & 0.0095 \\
\hline $\ln M_{t}$ & 3.639086 & 3 & 0.3032 & $\ln M_{t}$ & 1.051682 & 3 & 0.7887 \\
\hline All & 22.91493 & 9 & 0.0064 & All & $16 . .05493$ & 9 & 0.0657 \\
\hline \multicolumn{2}{|c|}{ Dependent Variable } & \multicolumn{2}{|c|}{$\ln \mathrm{TOT}_{\mathrm{t}}$} & \multicolumn{2}{|c|}{ Dependent Variable } & \multicolumn{2}{|c|}{$\operatorname{lnM}_{t}$} \\
\hline $\ln X_{t}$ & 7.401030 & 3 & 0.0602 & $\ln X_{t}$ & 4.043343 & 3 & 0.2568 \\
\hline $\ln \mathrm{Yw}_{\mathrm{t}}$ & 15.21657 & 3 & 0.0016 & $\ln \mathrm{Yw}_{\mathrm{t}}$ & 7.534212 & 3 & 0.0567 \\
\hline $\ln M$ & 7.213047 & 3 & 0.0654 & $\ln \mathrm{TOT}_{\mathrm{t}}$ & 15.26519 & 3 & 0.0016 \\
\hline All & 22.22993 & 9 & 0.0082 & All & 29.30932 & 9 & 0.0006 \\
\hline
\end{tabular}

Note: The VAR is estimated with three lagged differences. 


\section{Concluding Remarks}

The study examined the determinants of Japanese and German exports. We complemented the empirical econometric analysis with a brief synopsis of the history of the two countries. The historical review and the comparison of the two countries aimed to shed even more light on the nexus of the causal relations between exports and other relevant macroeconomic variables. We can summarize our findings as follows.

Different factors motivated Japan and Germany to pursue the births of their nation states. Japan reshaped itself in an effort to combat foreign counties that threatened its sovereignty through the imposition of unwanted trade treaties. To achieve these aims, Japan was fortunate to eliminate the tyrannical socioeconomic system of feudalism. Under the leadership of Otto Von Bismarck, Germany became a new state as it ambitiously expanded its territory, creating the Prussian Empire.

Both countries fiercely waged many wars to expand and maintain their colonies. The last one was WWII, in which they fought as allies. During these wars, they committed unparalleled atrocities against humanity, and the stigmas of these acts are impossible to overcome. Since the end of the WWII, the two countries have rebuilt their economies, and they are presently wealthy democracies, playing positive roles in world politics and the global economy. The only major exception is that both countries produce and export destructive weapons, causing major concerns about stability and peace in the world.

Since the 1970s, Japan and Germany have evolved to become dominant countries in the global economy in terms of exports and imports. However, Japanese exports have faced strong competition, mainly from China, Korea, and a few other East Asian countries, in more recent years (Athukorala, 2009). These factors have induced the Japanese government to depreciate its currency. After his election to office for a second term in December 2012, Prime Minister Shinzo Abe, together with the Governor of the Central Bank of Japan, Haruhiko Kuroda, launched a new macroeconomic program. With a combination of extraordinary expansive monetary and fiscal policies, this program attempted to release Japan from the stagnation and deflation conundrum that had persisted for over two decades. The new program, which became known as "Abenomics," achieved relative success because it restored the people's confidence in the economic system, even though the program's objectives (i.e., economic growth and two percent target inflation via ER depreciation by boosting Japanese exports) were never achieved. Abe's withdrawal from politics owing to his health does not seem to have helped Japan's economic recovery. Conversely, Germany's exports and economy continue to grow and seem to have weathered the global financial crisis more successfully. Germany seems to have benefited from its membership in the EU and the adoption of the euro, which has not appreciated, as its former currency (the Deutsche Mark) may have. Both countries, however, were negatively affected by the COVID-19 pandemic and 
interruptions to international supply chains. The two estimated ARDL models use global demand, price competitiveness, and imports as proxies for the explanatory variables, and they perform well in explaining exports.

\section{References}

Alimi, R. S. (2014). ARDL bounds testing approach to cointegration: A re-examination of augmented Fisher hypothesis in an open economy. Asian Journal of Economic Modelling, 2(2), 103-114.

Akkemik, K. A. (2015). Recent industrial policies in Japan. In Economic Planning and Industrial Policy in the Globalizing Economy (pp. 181-205). Springer, Cham.

Athukorala, P. C. (2009). The rise of China and East Asian export performance: Is the crowding-out fear warranted? World Economy, 32(2), 234-266.

Bahmani-Oskooee, M. M., \& Goswami, G. G. (2003). A disaggregated approach to test the J-curve phenomenon: Japan versus her major trading partners. Journal of Economics and Finance, 27(1), 102-113.

Bahmani-Oskooee, M., \& Mohammadian, A. (2017). Asymmetry effects of exchange rate changes on domestic production in Japan. International Review of Applied Economics, 31(6), 774-790.

Bahmani-Oskooee, M., \& Ratha, A. (2004). The J-curve: A literature review. Applied Economics, 36(13), 1377-1398.

Balassa, B. (1965). Trade liberalisation and "revealed" comparative advantage 1. The Manchester School, 33(2), 99-123.

Baldwin, R. E. (1971). Determinants of the commodity structure of US trade. The American Economic Review, 61(1), 126-146.

Bayoumi, T., Lee, J., \& Jayanthi, S. (2006). New rates from new weights. IMF Staff Papers, 53(2), 272-305.

Beattie, A., Cadman, E., \& Bernard, S. (2012, October 31). The currency wars explained. Financial Times. Retrieved from http://ig-legacy.ft.com/content/63de0284-db98-11df-aldf-00144feabdc0\#axzz740WWkdK4

Bhagwati, J. (1964). The pure theory of international trade: A survey. The Economic Journal, 74(293), $1-84$.

Clostermann, J. (1996). The impact of the exchange rate on Germany's balance of trade. Discussion Paper, No. 1996, 07e.

DeJong, D. N., Nankervis, J. C., Savin, N. E., \& Whiteman, C. H. (1992). The power problems of unit root test in time series with autoregressive errors. Journal of Econometrics, 53(1-3), 323-343.

Dickey, D. A., \& Fuller, W. A. (1979). Distribution of the estimators for autoregressive time series with a unit root. Journal of the American Statistical Association, 74(366a), 427-431.

Elliott, G., Rothenberg, T. J., \& Stock, J. (1996). Efficient tests for an autoregressive unit root. Econometrica, 64(4), 813-836.

Erber, G. (2016). Industrial Policy in Germany after the Global Financial and Economic Crisis. Available 
at SSRN 2756963.

Evans, J., \& Gibb, E. (2009). Moving from precarious employment to decent work. Geneva: GURN. Feenstra, R., \& Kee, H. L. (2008). Export variety and country productivity: Estimating the monopolistic competition model with endogenous productivity. Journal of International Economics, 74(2), 500-518.

Fukao, K. (2013). Explaining Japan's unproductive two decades. Asian Economic Policy Review, 8(2), 193-213.

Fukuda, S. I., \& Doita, T. (2016). Unconventional monetary policy and its external effects: Evidence from Japan's exports. The Developing Economies, 54(1), 59-79.

Granger, C. W. (1969). Investigating causal relations by econometric models and cross-spectral methods. Econometrica: Journal of the Econometric Society, 37(3), 424-438.

Haberler, G. V. (1936). Theory of international trade: With its applications to commercial policy. London: William Hodge and Company Limited.

Hausmann, R., Hwang, J., \& Rodrik, D. (2007). What you export matters. Journal of Economic Growth, $12(1), 1-25$.

Hooper, P., Johnson, K., \& Marquez, J. (1998). Trade elasticities for G-7 countries. FRB International Finance Discussion Paper, 609.

Horiba, Y. (1974). General equilibrium and the Heckscher-Ohlin theory of trade: The multi-country case. International Economic Review, 15(2), 440-449.

Houthakker, H. S., \& Magee, S. P. (1969). Income and price elasticities in world trade. The Review of Economics and Statistics, 51(2), 111-125.

Jiang, Y., Zestos, G. K., \& Timmerman, Z. (2020). A vector error correction model for Japanese real exports. Atlantic Economic Journal, 48(3), 297-311.

Johansen, S. (1991). Estimation and hypothesis testing of cointegration vectors in Gaussian vector autoregressive models. Econometrica: Journal of the Econometric Society, 59(6), 1551-1580.

Johansen, S. (1995). Likelihood-based inference in cointegrated vector autoregressive models. Oxford: Oxford University Press on Demand.

Kappler, M., \& Radowski, D. (2003). Der Außenhandelskanal. Finanzmärkte, Unternehmen und Vertrauen. Neue Wege der internationalen Konjunkturübertragung. ZEW Wirtschaftsanalysen, 64, 181-205.

Kawai, M., \& Urata, S. (2012). Changing commercial policy in Japan, 1985-2010. In M. E. Kreinin \& M. G. Plummer (Eds.), Oxford Handbook of International Commercial Policy (pp. 225-251). New York: Oxford University Press.

Lapp, S., Scheide, J., \& Solveen, R. (1995). Determinants of exports in the G7-countries. Kiel Working Paper, No. 707.

Lee, J. (2011). Export specialization and economic growth around the world. Economic Systems, 35(1), 45-63.

Leontief, W. (1953). Domestic production and foreign trade; the American capital position re-examined. Proceedings of the American Philosophical Society, 97(4), 332-349.

Mosk, C. (2000). Japanese industrial history: Technology, urbanization, and economic growth. ME Sharpe.

Myerson, R. B. (2004). Political economics and the Weimar disaster. Journal of Institutional and Theoretical Economics (JITE)/Zeitschrift für die gesamte Staatswissenschaft, 160(2)187-209. 
Neumann, H. (2020). The determinants of German exports-An analysis of intra-and extra-EMU trade. International Review of Applied Economics, 34(1), 126-145.

Nishijima, S. (2012). Japanese industrial policy. http://repositorio.ipea.gov.br/handle/11058/6422

Ng, S., \& Perron, P. (2001). Lag length selection and the construction of unit root tests with good size and power. Econometrica, 69(6), 1519-1554.

Ohno, K. (2006). The economic development of Japan: The path traveled by Japan as a developing country. GRIPS Development Forum.

Okazaki, T. (2007). Production organizations in Japanese economic development. Routledge.

Owen-Smith, E. (2012). The German economy. London: Routledge.

Pesaran, M. H., Shin, Y., \& Smith, R. J. (2001). Bounds testing approaches to the analysis of level relationships. Journal of Applied Econometrics, 16(3), 289-326.

Phillips, P. C., \& Perron, P. (1988). Testing for a unit root in time series regression. Biometrika, 75(2), 335-346.

Ricardo, D. (1817). On the principles of political economy and taxation. In P. Sraffa (Ed.), Works and Correspondence of David Ricardo (Vol. I). Cambridge University Press.

Samuelson, P. A. (1948). International trade and the equalisation of factor prices. The Economic Journal, 58(230), 163-184.

Samuelson, P. A. (1949). International factor-price equalisation once again. The economic journal, 59(234), 181-197.

Shimizu, J., \& Sato, K. (2015). Abenomics, yen depreciation, trade deficit, and export competitiveness. RIETI Discussion Paper Series.

Smith, A. (1776). The wealth of nations (Vol. 11937). London: W. Strahan and T. Cadell.

Stahn, K. (2006). Has the impact of key determinants of German exports changed? Results from estimations of Germany's intra euro-area and extra euro-area exports. SSRN Working paper. https://papers.ssrn.com/ sol3/papers.cfm?abstract_id $=2785233$

Stephan, S. (2006). German exports to the euro area. Empirical Economics, 31(4), 871-882.

Strauss, H. (2004). Demand and supply of aggregate exports of goods and services: Multivariate cointegration analyses for the United States, Canada, and Germany. Berlin: Springer Science \& Business Media.

Thorbecke, W., \& Kato, A. (2012a). The effect of exchange rate changes on Japanese consumption exports. Japan and the World Economy, 24(1), 64-71.

Thorbecke, W., \& Kato, A. (2012b). The effect of exchange rate changes on Germany's exports. Research Institute of Economy, Trade and Industry RIETI Discussion Paper Series.

Toda, H. Y., \& Yamamoto, T. (1995). Statistical inference in vector autoregressions with possibly integrated processes. Journal of Econometrics, 66(1-2), 225-250.

Van Ark, B., Pilat, D., Jorgenson, D., \& Lichtenberg, F. R. (1993). Productivity levels in Germany, Japan, and the United States: Differences and causes. Brookings Papers on Economic Activity. Microeconomics, 1993(2), 1-69.

Vanek, J. (1968). The factor proportions theory: The $\mathrm{n}$-factor case. Kyklos, 21(4), 749-756.

Zestos, G. K. (2016). The global financial crisis: From US subprime mortgages to European sovereign 
debt. London: Routledge.

Zestos, G. K., \& Benedict, J. M. (2018). European Monetary Integration: A History. Encyclopedia of International Economics and Global Trade.

Zestos, G. K., \& Cooke, R. N. (2020). Challenges for the EU as Germany Approaches Recession. New York: Levy Economics Institute.

Zestos, G. K., Taylor, T. K., \& Patnode, R. D. (2016). Causality within the euro area? Trade surplus in the north versus public debt in the south. Journal of Economic Integration, 31(4), 898-931. 